\title{
PENGARUH PENGEMBANGAN KARIR DAN IKLIM ORGANISASI TERHADAP KEPUASAN KERJA PEGAWAI PADA PUSKESMAS MANGASA DI MAKASSAR
}

\author{
Muhammad Carda P*) \\ Dosen STIE Wira Bhakti Makassar
}

\begin{abstract}
Abstrak
Penelitian ini bertujuan: 1) untuk menganalisis pengaruh pengembangan karir terhadap kepuasan kerja pegawai pada Puskesmas Mangasa di Makassar, 2) untuk menganalisis pengaruh iklim organisasi terhadap kepuasan kerja pegawai pada Puskesmas Mangasa di Makassar. Dalam penelitian ini digunakan metode analisis regresi berganda. Data penelitian yang digunakan diperoleh dari wawancara, dokumentasi dan kuesioner.

Hasil penelitian ini menunjukkan bahwa: 1) berdasarkan hasil uji regresi berganda, pengaruh variabel pengembangan karir berpengaruh positif dan signifikan terhadap kepuasan kerja pada pegawai Puskesmas Mangasa di Makassar. Pengembangan karir di Puskesmas Mangasa di Makassar pada dasarnya adalah peningkatan kinerja pegawai yang mencerminkan kemampuan organisasi dalam bekerja, artinya kinerja masing-masing karyawan di nilai dan di ukur dalam nilai dan kriteria yang sudah ditentukan oleh organisasi, dan 2) berdasarkan hasil uji regresi berganda, pengaruh variabel iklim organisasi berpengaruh positif dan signifikan terhadap kepuasan kerja pada pegawai Puskesmas Mangasa di Makassar. Kepuasan kerja pegawai pada Puskesmas Mangasa di Makassar bisa terjadi jika pegawai merasa memperoleh perasaan keadilan dalam melakukan pekerjaan. Adanya iklim organisasi yang dirasa adil akan mendorong pegawai untuk segera mencapai kepuasan dalam bekerja.
\end{abstract}

Kata Kunci: Pengembangan Karir, Iklim Organisasi dan Kepuasan Kerja

\begin{abstract}
This study aims: 1) to analyze the effect of career development on employee job satisfaction at the Mangasa Health Center in Makassar, 2) to analyze the influence of the organizational climate on employee job satisfaction at the Mangasa Health Center in Makassar. This research uses a multiple regression analysis method. The research data used were obtained from interviews, documentation and questionnaires.

The results of this study indicate that: 1) based on the results of multiple regression tests, the influence of career development variables has a positive and significant effect on job satisfaction of employees of the Mangasa Health Center in Makassar. Career development at the Mangasa Health Center in Makassar is basically an increase in employee performance that reflects the ability of the organization in work, meaning that the performance of each employee is rated and measured in terms of values and criteria determined by the organization, and 2) based on the results of multiple regression tests, the influence of organizational climate variables has a positive and significant effect on job satisfaction of Mangasa Health Center employees in Makassar. Employee job satisfaction at the Mangasa Health Center in Makassar can occur if employees feel they have a feeling of justice in doing work. An organizational climate that is considered fair will encourage employees to immediately achieve satisfaction at work.
\end{abstract}

Keywords: Career Development, Organizational Climate and Job Satisfaction

\section{PENDAHULUAN}

Manusia memang dilahirkan dengan seribu satu masalah, kompleks, unik, pelik untuk dipahami, karena antar manusia. berbeda dengan manusia lainnya, tidak demikian halnya bila dibandingkan dengan mesin atau peralatan kerja lainnya. Masalah yang 
dijumpai pada mesin, akan mudah ditanggulangi ataupun diperbaiki, sehingga masalah yang terjadi pada sumber daya manusia memerlukan keahlian untuk mengatasinya. Untuk menyelesaikan masalah-masalah yang berkaitan dengan sumber daya manusia, dalam hal ini perusahaan perlu memperhatikan pengembangan karir dan iklim organisasi yang akan meningkatkan kinerja di organisasi. Dengan demikian, produktivitas kerja pegawai organisasi dari kepuasan pegawai dapat tercapai dan akhirnya kinerja di organisasi dapat ditingkatkan dari waktu ke waktu (Nawawi, 2013:198).

Pengembangan karir adalah proses peningkatan kemampuan kerja individu yang dicapai dalam rangka mencapai karir yang diinginkan. Dapat disimpulkan suatu pemahaman bahwa pengembangan karir adalah suatu proses berkesinambungan yang dilalui individu melalui upayaupaya pribadi dalam rangka mewujudkan tujuan perencanaan karirnya yang disesuaikan dengan kondisi organisasi. Pengembangan karir adalah upaya yang dilakukan oleh organisasi dalam merencanakan karir pegawainya, yang disebut sebagai manajemen karir, antara lain merencanakan, melaksanakan dan pengawasan karir. Pengembangan karir sangat diharapkan oleh setiap pegawai untuk memotivasi mereka dalam bekerja dengan baik. Dalam implementasinya, pengembangan karir lebih cendrung merupakan implementasi dari perencanaan karir (Marihot, 2010:89)

Iklim organisasi memiliki hubungan dengan kepuasan kerja, iklim kerja yang positif mengakibatkan tingginya kepuasan kerja. Iklim organisasi adalah persepsi anggota organisasi (secara individu atau kelompok) dan mereka secara tetap berhubungan dengan organisasi, mengenai apa yang ada atau terjadi di lingkungan internal organisasi secara rutin, yang mempengaruhi sikap dan perilaku organisasi dan kinerja anggota organisasi yang kemudian menentukan kinerja organisasi. Puskesmas atau pusat kesehatan masyarakat adalah suatu unit pelaksana fungsional yang berfungsi sebagai pusat pembangunan kesehatan, pusat pembinaan peran serta masyarakat dalam bidang kesehatan serta pusat pelayanan kesehatan tingkat pertama yang menyelenggarakan kegiatannya secara menyeluruh, terpadu, dan berkesinambungan pada suatu masyarakat yang bertempat tinggal dalam suatu wilayah tertentu (Rivai, 2013:302).

Puskesmas Mangasa di Makassar merupakan unit pelaksana teknis dinas (UPTD) kesehatan kabupaten/kota yang bertanggungjawab menyelenggarakan pembangunan kesehatan disuatu wilayah. Kinerja pegawai pada Puskesmas Mangasa di Makassar adalah suatu kesatuan organisasi fungsional yang memberikan pelayanan secara menyeluruh kepada masyarakat dalam bentuk usahausaha kesehatan pokok. Jenis pelayanan kesehatan pada Puskesmas Mangasa di Makassar disesuaikan dengan kemampuan puskesmas, namun terdapat upaya kesehatan wajib yang harus dilaksanakan oleh puskesmas ditambah dengan upaya kesehatan pengembangan yang disesuaikan dengan permasalahan yang ada serta kemampuan puskesmas.

Adanya kesempatan pengembangan karir dan iklim organisasi diorganisasi tempat bekerja akan dapat mendukung suasana kerja yang baik dan mendorong pegawai berkarya bagi organisasi. Pengembangan karir merupakan hal yang paling penting dalam mengembangkan dan memperhatikan sumber daya manusia. Pengembangan karir sangat mendukung efektivitas individu kelompok dan organisasi dalam mencapai tujuan serta menciptakan kepuasan kerja. Iklim organsasi memberikan pengaruh besar terhadap kepuasan kerja. Untuk itu 
dalam perusahaan, rendahnya kinerja karyawan dapat dilihat dari tanggung jawab yang rendah, disiplin yang kurang, kemampuan kerja yang rendah, tingginya labour turnover (tingkat keluar masuk kerja) hal ini mencerminkan kepuasan kerja pegawai rendah (Husein, 2014:36).

\section{TINJAUAN PUSTAKA}

\section{A. Pengembangan Karir}

Karir seseorang dalam suatu organisasi banyak ditentukan oleh bagaimana kebijakan dan komitmen organisasi tersebut terhadap karyawannya. Nawawi (2016:181) menyatakan bahwa pengembangan karir adalah pendekatan formal yang digunakan organisasi untuk memastikan bahwa orang dengan kualifikasi dan pengalaman yang tepat tersedia jika dibutuhkan. Karir merupakan keseluruhan jabatan yang mungkin diduduki seseorang dalam organisasi dengan tujuan jabatan tertinggi yang akan diduduki seseorang dalam suatu organisasi.

Handoko (2011:45), karir adalah semua pekerjaan atau jabatan yang ditangani atau dipegang selama kehidupan kerja seseorang. Dengan demikian karir menunjukkan perkembangan para karyawan secara individual dalam jenjang jabatan atau kepangkatan yang dapat dicapai selama masa kerja dalam suatu organisasi. Mangkunegara (2015:102) mendefinisikan pengembangan karir sebagai aktivitas kepegawaian yang membantu pegawai merencanakan karier masa depan di perusahaan agar perusahaan dan pegawai yang bersangkutan dapat mengembangkan diri secara maksimum.

Rosidah dan Ambar (2012:97), pengembangan karir merupakan usaha secara formal dan terorganisir serta terencana untuk mencapai keseimbangan antara kepentingan karir individu dengan organisasi secara keseluruhan.
Rivai (2013:253) mengemukakan bahwa, pengembangan karir adalah proses peningkatan kemampuan kerja individu yang dicapai dalam rangka mencapai karir yang diinginkan. Jadi, pengembangan karir merupakan tindakan seorang pegawai untuk mencapai rencana karirnya, yang disponsori baik oleh departemen sumber daya manusia, manajer atau pun pihak lain. Rivai (2013:253) ada beberapa prinsip yang perlu diperhatikan dalam pengembangan karir:

a. Pekerjaan berpengaruh paling besar terhadap pengembangan karir, karena setiap kali muncuk tantangan yang berbeda, maka apa yang dipelajari dari pekerjaan bias jauh lebih penting daripada aktivitas pengembangan yang direncanakan secara formal.

b. Jenis keterampilan baru yang akan dibutuhkan ditentukan oleh persyaratan jabatan yang spesifik.

c. Pengembangan akan terjadi bila seseorang belum memperoleh keterampilan yang disyaratkan oleh suatu jabatan tertentu.

Tujuan program pengembangan karir adalah untuk menyesuaikan antara kebutuhan dan tujuan pegawai dengan kesempatan karir yang tersedia di perusahaan saat ini dan di masa mendatang. Rivai (2013:280) bahwa pengembangan karir yang dirancang secara baik akan membantu pegawai dalam menentukan kebutuhan karir mereka sendiri, dan menyesuaikan antara kebutuhan pegawai dengan tujuan organisasi. Tujuan pengembangan karir Mangkunegara (2015:56) adalah:

a. Membantu dalam pencapaian tujuan individu dan perusahaan Seorang pegawai yang sukses dengan prestasi kerja yang sangat baik kemudian menduduki posisi jabatan yang lebih tinggi 
b. Menunjukkan hubungan kesejahteraan pegawai

Perusahaan merencanakan karir pegawai dengan meningkatkan kesejahteraannya agar pagawai lebih tinggi loyalitasnya.

c. Membantu pegawai menyadari kemampuan potensi mereka

Membantu pegawai akan kemampuannya untuk menduduki suatu jabatan tertentu sesuai dengan potensi dan keahliannya

d. Memperkuat hubungan antara pegawai dan perusahaan.

Pengembangan karir akan memperkuat hubungan dan sikap pegawai terhadap perusahaannya

e. Membuktikan tanggung jawab sosial

Pengembangan karir suatu cara menciptakan iklim kerja dalam organisasi yang positif dan pegawai menjadi lebih bermental sehat.

f. Membantu memperkuat pelaksanaan program-program perusahaan agar tujuan perusahaan tercapai.

g. Mengurangi turnover dan biaya kepegawaian

Pengembangan karir dapat menjadikan turnover rendah dan begitu pula biaya kepegawaian menjadi lebih efektif.

h. Mengurangi keusangan profesi dan manajerial.

Pengembangan karir dapat menghindarkan dari keusangan dan kebosanan profesi dan manajerial.

i. Menggiatkan analisis dari keseluruhan pegawai

Perencanaan karir dimaksudkan mengintegrasikan perencanaan kerja dan kepegawaian.

Rivai (2013:253) aspek-aspek yang terdapat dalam pengembangan karir individu adalah:

a. Prestasi kerja (Job Performance)
Merupakan komponen yang paling penting untuk pengembangan karir yang paling penting untuk meningkatkan dan mengembangkan karir seorang karyawan. Kemajuan karir sebagian besar tergantung atas prestasi kerja yang baik dan etis. Dengan mengetahui hasil atas kinerjanya maka karyawan dalam perusahaan dapat mengukur kesempatannya terhadap pengembangan karir.

b. Pengenalan oleh pihak lain (Exposure)

Tanpa pengenalan oleh pihak lain maka karyawan yang baik tidak akan mendapatkan peluang yang diperlukan guna mencapai tujuan mereka. Manajer memperoleh pengenalan ini terutama melalui kinerja, dan prestasi karyawan.

c. Jaringan kerja (Net working) Jaringan kerja berarti perolehan eksposure di luar perusahaan. Mencakup kontak pribadi dan professional. Jaringan tersebut akan sangat bermanfaat bagi karyawan terutama dalam pengembangan karirnya.

d. Pengunduran diri (resignation)

Kesempatan berkarier yang banyak dalam sebuah perusahaan memberikan kesempatan untuk pengembangan karir karyawan, hal ini akan mengurangi tingkat pengunduran diri untuk mengembangkan diri di perusahaan lain (leveraging).

e. Kesetiaan terhadap organisasi (Organization loyalty)

Level loyalitas yang rendah merupakan hal yang umum terjadi di kalangan lulusan perguruan tinggi terkini yang disebabkan ekspektasi terlalu tinggi pada perusahaan tempatnya bekerja pertama kali sehingga seringkali menimbulkan kekecewaan. Hal yang sama juga terjadi pada kelompok profesional dimana 
loyalitas pertamannya diperuntukkan bagi profesi.

f. Pembimbing dan sponsor (Mentors and sponsors)

Adanya pembimbing dan sponsor akan membantu karyawan dalam mengembangkan karimya. Pembimbing akan memberikan nasehat atau saran kepada karyawan dalam upaya pengembangan karirnya, pembimbing berasal dari internal perusahaan. Mentor adalah seseorang di dalam perusahaan yang menciptakan kesempatan untuk pengembangan karirnya karyawan.

g. Bawahan yang mempunyai peran kunci (Key subordinate)

Atasan yang berhasil memiliki bawahan yang membantu kinerja mereka. Bawahan dapat memiliki pengetahuan dan keterampilan khusus sehingga atasan dapat belajar darinya.

h. Peluang untuk tumbuh (Growth opportunities)

Karyawan hendaknya diberikan kesempatan untuk meningkatkan kemampuannya, misalnya melalui pelatihan-pelatihan, kursus, dan melanjutkan pendidikannya. Hal ini akan memberikan karyawan kesempatan untuk tumbuh dan berkembang sesuai dengan rencana karirnya.

i. Pengalaman intemasional (International experience)

Untuk orang-orang yang mendekati posisi operasional atau staf senior, maka pengalaman internasional menjadi peluang pertumbuhan yang sangat penting. Khususnya bagi perusahaan-perusahaan domestik dimana penjualan tinggi berasal dari operasi internasional, juga bagi perusahaan yang telah mengglobal.

Siagian (2012:233) berpendapat bahwa faktor-faktor yang mempengaruhi perkembangan karir seorang karyawan adalah sebagai berikut: a. Prestasi kerja yang memuaskan

Pangkal tolok pengembangan karir adalah prestasi kerjanya melakukan tugas yang dipercayakan kepadanya. Tanpa prestasi kerja yang memuaskan, sulit bagi seorang pekerja untuk diusulkan oleh atasannya agar dipertimbangkan untuk dipromosikan ke jabatan yang lebih tinggi di masa depan.

b. Pengenalan oleh pihak lain

Yang dimaksud di sini adalah berbagai pihak yang berwenang memutuskan layak tidaknya seseorang dipromosikan seperti atasan langsung dan pimpinan bagian kepegawaian

c. Kesetiaan pada organisasi

Hal ini berhubungan dengan dedikasi seorang pegawai yang ingin terus berkarya dalam organisasi tempatnya bekerja.

d. Pembimbing dan sponsor.

Pembimbing adalah orang yang memberikan nasehat atau saran-saran kepada karyawan dalam upaya mengembangkan karirnya. Sponsor adalah seseorang di dalam perusahaan yang dapat menciptakan kesempatan bagi karyawan untuk mengembangkan karimya.

e. Dukungan para bawahan

Merupakan dukungan yang diberikan para bawahan dalam bentuk mensukseskan tugas manajer yang bersangkutan.

f. Kesempatan untuk bertumbuh

Merupakan kesempatan yang diberikan kepada karyawan untuk meningkatkan kemampuannya, baik melalui pelatihan-pelatihan, kursus, dan juga melanjutkan jenjang pendidikannya.

g. Berhenti atas permintaan dan kemauan sendiri.

Merupakan keputusan seorang karyawan untuk berhenti bekerja dan beralih ke perusahaan lain yang 
memberikan kesempatan lebih besar untuk mengembangkan karir.

\section{B. Iklim Organisasi}

Iklim organisasi (organisasi climate) pertama kali dipakai oleh Kurt Lewin pada tahun 1990-an, yang menggunakan istilah iklim psikologi (psiychological climate). Kemudian istilah iklim organisasi dipakai oleh Taguari dan Litwin (2008:121). Selanjutnya Taguari mengemukakan sejumlah istilah untuk melukiskan perilaku dalam hubungan dengan latar dan tempat (setting) dimana perilaku muncul: lingkungan (environment), pola lapangan (field setting), budaya (culture), suasana (atmosphere), situasi (situation). Lingkungan pergaulan (milieu), pola perilaku (behavior setting), dan kondisi (condition). Iklim organisasi (organisasi climate).

Wirawan (2011:121), iklim organisasi merupakan kualitas lingkungan internal organisasi yang secara relatif terus berlangsung, dialami oleh anggota organisasi, memengaruhi perilaku mereka dan dapat dilukiskan dalam pengertian satu set karakteristik atau sifat organisasi. Davis dan Newstorm (2011:65) mengemukakan pengertian iklim organisasi sebagai The human environment within an organi-zation's employees do their work. Pernyataan Davis tersebut mengandung arti bahwa iklim organisasi itu adalah yang menyangkut semua lingkungan yang ada atau yang dihadapi oleh manusia di dalam suatu organisasi tempat mereka melaksanakan pekerjaannya. Davis dan Newstom (2011:65) juga mengemukakan iklim organisasi merupakan sebuah konsep yang menggambarkan suasana internal lingkungan organisasi yang dirasakan oleh anggotanya selama beraktivitas dalam rangka tercapainya tujuan organisasi.
Litwin dan Stringer, (2008:5), iklim organisasi merupakan efek persepsi subjektif terhadap sistem formal, gaya informal manajer, dan faktor-faktor lingkungan lain yang berpengaruh pada sikap, keyakinan, nilai, dan motivasi dari orang-orang yang bekerja pada suatu perusahaan tertentu. Gilmer (2011:49) mendefinisikan Iklim organisasi merupakan karakteristik karakteristik tertentu yang membedakan suatu organisasi dengan organisasi lainnya dan mempengaruhi tingkah laku manusia di dalam organisasi tersebut. Gilmer menguraikan bahwa iklim organisasi tidak hanya mempengaruhi tingkah laku individu-individu dalam organisasi, tetapi juga bagaimana organisasi tersebut berinteraksi dengan yang lain.

Davis (2012:104), iklim organisasi merupakan sebagai lingkungan manusia dimana karyawan atau anggota organisasi melakukan pekerjaannya. Pengertian ini dapat mengacu pada lingkungan suatu departemen, unit perusahaan yang penting seperti anak perusahaan, atau suatu organisasi secara keseluruhan. Milton (2011:458), iklim organisasi didefinisikan sebagai kualitas dari lingkungan internal yang secara relatif bertahan lama, menjadi pengalaman bagi setiap anggota organisasi, mempengaruhi perilaku mereka, dapat didiskusikan dalam suatu set karakteristik atau atribut (sifat) dan menjadi pembeda antara satu organisasi dengan organisasi lainnya. Iklim organisasi juga merupakan perasaan yang membawa suatu kelompok dalam tata ruang fisik dan arah dimana para anggota organisasi berinteraksi dengan orang lain baik kepada para langganan maupun kelompok lain. Iklim organisasi adalah keadaan psikologi/emosional dari keseluruhan harapan, pendapat dan pengalaman yang dirasakan oleh karyawan berkenaan dengan keseluruhan situasi kerjanya dalam melaksanakan 
tugasnya yang meliputi: kerjasama, gairah kerja, keterbukaan dalam berkomunikasi, toleransi, keakraban, disiplin serta gaya kepemimpinan organisasi.

Dari beberapa definisi di atas dapat disimpulkan bahwa iklim organisasi yang dialami oleh karyawan yang berada dalam suatu organisasi adalah bagaimana karakteristik yang berasal dari lingkungan berpengaruh terhadap tingkah laku orang yang berada dalam organisasi serta segala sesuatu yang ada dalam organisasi seperti sistem formal, gaya kepemimpinan manajer (informal/formal), faktor lingkungan penting lainnya yang akan berpengaruh terhadap sikap, kepercayaan, nilai dan motivasi orang yang bekerja dalam organisasi tersebut.

Timpe (2012:457) menerangkan bahwa konsep iklim organisasi pertama kali dikemukakan oleh Litwin dan Stringer diukur melalui lima dimensi, yaitu:

a. Responsibility (tanggung jawab), adalah perasaan menjadi pimpinan bagi diri sendiri, tidak selalu harus mengecek ulang semua keputusan yang diambil. Ketika karyawan mendapat suatu pekerjaan, karyawan yang bersangkutan mengetahui bahwa itu adalah pekerjaanya,

b. Identity (identitas), adalah perasaan memiliki (sense of belonging) terhadap perusahaan dan diterima dalam kelompok,

c. Warmth (kehangatan) adalah perasaan terhadap suasana kerja yang bersahabat dan lebih ditekankan pada kondisi keramahan atau persahabatan dalam kelompok yang informal, serta hubungan yang baik antar rekan kerja, penekanan pada pengaruh persahabatan dan kelompok social yang informal,

d. Support (dukungan), adalah hal-hal yang terkait dengan dukungan dan hubungan antar sesama rekan kerja yaitu perasaan saling menolong antara manajer dan karyawan, dan lebih ditekankan pada dukungan yang saling membutuhkan antara atasan dan bawahan,

e. Conflict (konflik) adalah merupakan situasi terjadinya pertentangan atau perbedaan pendapat antara bawahan dengan pimpinan dan bawahan dengan bawahan.

Souder (2007:88) menyatakan mengidentifikasi ada lima dimensi iklim organisasi yang berpengaruh terhadap suksesnya inovasi dan pengembangan produk, yaitu:

a. Iklim kerja yang memiliki ketidakmenentuan dalam tugas dan tanggung jawab karyawan cenderung tidak inovatif

b. Iklim kerja yang memiliki flexibiltas peran dan tanggung jawab (role flexsibility) lebih tinggi di dalam pekerjaan cenderung lebih berinovasi.

c. Iklim yang mendorong keterbukaan dan trust cenderung lebih inovatif.

d. Dukungan manajemen memegang peran krusial bagi suksesnya sebagian proyek inovasi

e. Komunikasi intensif (baik dari sisi volume maupun frekuensi) di dalam organisasi cenderungmendorong inovasi.

Secara tegas dikatakan bahwa iklim merupakan "seperangkat ciri-ciri khas" organisasi alias tanda pengenal yang membedakan dengan organisasiorgnisasi lain. Iklim juga bertahan cukup lama memiliki :pengaruh pada perilaku orang-orang dalam organisasi" karyawan pada umumnya termasuk jajaran pimpinan. Timpe (2012:375) berpendapat bahwa terdapat iklim yang bagus apabila organisasi memiliki kecenderungan:

a. Adanya sportivitas dalam hal komunikasi atasan bawahan 
(supporttivenees of superior subordinate communication),

b. Kualitas personal dan keakuratan yang menyangkut komunikasi dari atasan kepada bawahan (personal quality and accuracy of down ward communication),

c. Adanya nuansa keterbukaan dalam hubungan atasan dan bawahan (preceived opennes of the superior subordinate relationship)

d. Adanya peluang bagi bawahan untuk menyampaikan aspirasi dan atau saran-saran kepada atasan (opportunities and degree of influence of up ward communication)

e. Adanya jaminan yang bersifat relatif yang menyangkut informasi dari bawahan serta rekan kerja (perceived reliability of information from subordinates and co work)

Timpe (2012:477) ada empat prinsip faktor-faktor yang mempengaruhi iklim organisasi, yaitu:

a. Pada dasarnya setiap tindakan yang diambil oleh pimpinan atau manajer mempengaruhi iklim dalam beberapa hal, seperti aturan-aturan, kebijakan-kebijakan, dan prosedurprosedur organisasi terutama masalah-masalah yang berhubungan dengan masalah personalia, distribusi imbalan, gaya komunikasi, cara-cara yang digunakan untuk memotivasi, teknik-teknik dan tindakan pendisiplinan, interaksi antara manajemen dan kelompok, interaksi antar kelompok, perhatian pada permasalahan yang dimiliki karyawan dari waktu ke waktu, serta kebutuhan akan kepuasan dan kesejahteraan karyawan.

b. Tingkah laku karyawan mempengaruhi iklim melalui kepribadian mereka, terutama kebutuhan mereka dan tindakan-tindakan yang mereka lakukan untuk memuaskan kebutuhan tersebut. Komunikasi karyawan memainkan bagian penting dalam membentuk iklim. Cara seseorang berkomunikasi menentukan tingkat sukses atau gagalnya hubungan antar manusia. Berdasarkan gaya normal seseorang dalam hidup atau mengatur sesuatu, dapat menambahnya menjadi iklim yang positif atau dapat juga menguranginya menjadi negative

c. Terdapat kebutuhan tertentu pada kebanyakan orang dalam hal hubungan persahabatan, suatu kebutuhan yang seringkali dipuaskan oleh kelompok dalam organisasi. Kelompokkelompok berkembang dalam organisasi dengan dua cara, yaitu secara formal, utamanya pada kelompok kerja; dan informal, sebagai kelompok persahabatan atau kesamaan minat

d. Sejumlah faktor ekstemal organisasi mempengaruhi iklim pada organisasi tersebut.

\section{Kepuasan Kerja}

Kepuasan dalam bekerja atau kepuasan kerja yang merupakan sikap umum seorang individu terhadap pekerjaannya dapat terjadi pada semua tingkatan dalam suatu organisasi, misalnya ditingkat manajer terendah hingga ketingkat karyawan (Robbins, 2011:376). Kepuasan kerja adalah sikap umum individu terhadap pekerjaannya. Seseorang dengan tingkat kepuasan kerja yang tinggi mempunyai sikap positif terhadap pekerjaannya, seseorang yang tidak puas mempunyai sikap negatif terhadap pekerjaannya.

Marihot (2010:165) mengemukakan bahwa kepuasan kerja menunjukkan hingga sejauh mana individu merasakan secara positif atau negatif berbagai macam faktor dari tugas dalam pekerjaannya. Kepuasan kerja didasari pada enam dimensi yaitu gaji, pekerjaan itu sendiri, atasan, rekan kerja, promosi dan lingkungan kerja. Rivai (2013:283) 
kepuasan kerja pada dasarnya merupakan sesuatu yang bersifat individual. Setiap individual memilki tingkat kepuasan yang berbeda-beda sesuai dengan sistem nilai yang berlaku pada dirinya. Makin tingggi penilaian terhadap kegiatan yang dirasakan sesuai dengan keinginan individu, maka makin tinggi pula kepuasannya terhadap keinginan tersebut.

Husein (2014:51) menyatakan bahwa kepuasan kerja didefinisikan sebagai keadaan emosi yang menyenangkan atau positif yang berasal dari penilaian pekerjaan atau pengalaman kerja seseorang. Sejumlah faktor yang mempengaruhi kepuasan kerja. Beberapa faktor utamanya adalah pekerjaan itu sendiri, gaji, promosi, pengawasan, kelompok kerja, dan kondisi kerja. Dengan demikian dapat disimpulkan bahwa kepuasan kerja adalah suatu kondisi mental seseorang mengenai suka atau tidak suka terhadap pekerjaannya yang dipengaruhi oleh persepsi dan harapannya terhadap pekerjannya yang akan mempengaruhi perilaku kerjanya.

Robbins (2011:451) menyebutkan bahwa komponen-komponen yang menentukan kepuasan kerja adalah:

a. Kerja yang secara mental menantang akan membuat karyawan lebih menyukai pekerjaan yang dapat memberikan kesempatan untuk menggunakan keterampilan dan kemampuan kerja mereka serta menawarkan beragam tugas, kebebasan dan umpan balik bagi karyawan.

b. Ganjaran yang pantas dalam hal ini yang dimaksud adalah karyawan menginginkan sistem upah dan kebijakan promosi yang dipersepsikan sebagai adil dan sesuai dengan harapan mereka.

c. Kondisi kerja yang mendukung mempunyai arti karyawan yang peduli dengan lingkungan kerja, baik untuk kenyamanan pribadi maupun untuk memudahkan dalam melakukan pekerjaan yang baik.

d. Rekan kerja yang mendukung apabila karyawan mendapatkan lebih daripada sekedar uang atau prestasi dalam melaksanakan pekerjaannya.

e. Kesesuaian kepribadian dengan pekerjaan, pada hakikatnya karyawan dengan tipe kepribadian kongruen dengan pekerjaan akan memilih dan menemukan bakat serta kemampuan yang tepat untuk memenuhi tuntutan dari pekerjaan mereka.

Kondisi-kondisi yang mempengaruhi kepuasan kerja seseorang dapat dibagi menjadi dua, yaitu:

\section{a. Kondisi Organisasional}

Husein (2014:108) terdapat kondisi-kondisi yang berada dalam lingkungan organisasi atau lingkungan kerja yang mempengaruhi tingkat kepuasan kerja karyawan:

1. Unsur-unsur dalam pekerjaan Unsur-unsur seperti tantangan dalam pekerjaan dan variasi dalam pekerjaan mempengaruhi kepuasan kerja karyawan. Sebab unsur-unsur ini akan menarik minat karyawan dan dengan sendirinya akan membuat karyawan semakin terlibat dengan pekerjaannya. Hanya saja tingkat tantangan dan variasinya harus berada pada level sedang, sebab level terlalu tinggi justru mengakibatkan frustasi.

2. Sistem penggajian

Sistem penggajian mempengaruhi kepuasan kerja karyawan karena merupakan imbalan yang diterima karyawan atas usaha dan produktivitas yang telah dilakukan, selain itu juga berperan sebagai alat pemuas kebutuhan, fisik, simbol status, maupun menciptakan rasa aman. Sistem penggajian yang dipersepsikan 
adil dan kuat akan menimbulkan kepuasan kerja bagi karyawan.

3. Promosi

Kesempatan untuk dipromosikan akan menimbulkan kepuasan kerja sebab berkaitan dengan kenaikkan gaji, pengakuan, perasaan dihargai dan simbol status.
4. Pengakuan verbal (Verbal recognition)

Pengakuan dapat menimbulkan kepuasan kerja, terutama bagi karyawan bawah, sebab kebutuhan untuk merasa dihargai akan terpenuhi sesuai dengan kebutuhan harga diri, dan konsep diri.

5. Kondisi lingkungan kerja

Kondisi lingkungan kerja yang menyenangkan akan menimbulkan kepuasan kerja, sebab kondisi lingkungan yang baik akan mendukung penyelesaian pekerjaan.

6. Desentralisasi kekuasaan

Desentralisasi yang dimaksudkan adalah pembagian wewenang dan kekuasaan, dengan tidak memberikan pada satu orang saja. Hal ini akan menimbulkan kepuasan sebab karyawan dapat berpatisipasi dalam pengambilan keputusan, dan akan terpenuhi kebutuhan akan rasa kompetensi diri yang dimiliki dan otonomi.

7. Supervisi, rekan kerja dan bawahan

Supervisi yang dimaksud adalah persepsi dari karyawan terhadap kualitas dari atasan (supervisi) yang mencakup, gaya pengawasan, teknik pengawasan, kemampuan hubungan interpersonal, dan kemampuan administrasi. Sedangkan rekan sekerja dan bawahan berkaitan dengan masalah kompetensi, kesediaan menolong, sertapersahabatan.

8. Kebijakan perusahaan

Kebijakan yang dimaksud adalah menyangkut masalah administrasi, prosedur kerja, peraturan, kebijaksanaan dan tindakan yang diambil untuk kepentingan perusahaan. Kebijaksanaan dan peraturan yang ditetapkan organisasi akan menentukan jenis tugas, dan pekerjaan, beban tugas, derajat tanggung jawab, kesempatan promosi, tingkat gaji, serta kondisi fisik lingkungan kerja. Karyawan akan merasakan kepuasan kerja pada organisasi yang kebijakannya akan membantu karyawan memperoleh apa yang dibutuhkannya.

\section{b. Kondisi Personal}

Faktor-faktor yang dimaksudkan di sini adalah faktor-faktor pribadi yang ada dalam diri karyawan. Dengan kata lain faktor personal adalah perbedaan-perbedaan individu yang akan mempengaruhi kepuasan kerja (Husein, 2014:110), yaitu:

1. Keadaan demografis

Mencakup karakteritik pada diri karyawan antar lain usia, jenis kelamin, dan tingkat pendidikan. Karyawan yang lebih tua lebih berpengalaman sehingga lebih memiliki kesempatan dalam pemenuhan kebutuhan aktualisasi diri. Mereka juga memiliki kesadaran akan lebih sedikitnya kesempatan memperoleh kerja yang lebih baik sehingga selalu berusaha untuk membuat situasi lebih baik dalam kondisi seburuk apapun.

2. Variabel kepribadian

Yang dimaksud adalah tingkat harga diri, locus of control, dan kemampuan toleransi terhadap stres. Semakin banyak variabel ini dimiliki karyawan maka kepuasan kerjanya semakin tinggi.

3. Tingkat intelegensi

Tingkat intelegensi yang terlalu tinggi atau terlalu rendah akan lebih memungkinkan mengalami kebosanan dan ketidakpuasan kerja. Ketidak 
sesuaian antara tingkat intelegensi dengan jenis pekerjaan akan menimbulkan ketidakpuasan kerja

4. Pengalaman kerja

Tidak adanya pengalaman kerja bagi pemula, membuat pekerjaan menjadi menantang serta memungkinkan mereka mengembangkan kemampuan dan pengalaman, namun semakin berpengalaman maka pekerjaannya semakin kurang menantang sehingga menimbulkan ketidakpuasan.

5. Penggunaan keterampilan

Karyawan yang baru lulus sering mengalami ketidakpuasan karena tidak ada kesempatan untuk menerapkan keterampilan yang dimiliki hasil perguruan tinggi. Mereka merasa tidak dapat memperlihatkan unjuk kerja baik dan optimal yang disebabkan keterampilan efektif dalam melakukan pekerjaan belum dimiliki.

6. Tingkat jabatan

Semakin tinggi tingkat jabatan semakin tinggi kepuasan kerja hal ini disebabkan karena semakin tinggi tingkat jabatan semakin baik kondisi lingkungan, terpenuhi kebutuhan-kebutuhan motivasi, juga semakin besar tantangan, otonomi, dan tanggung jawab.

\section{METODE PENELITIAN}

\section{Populasi dan Sampel}

\section{Populasi}

Populasi dalam penelitian ini adalah seluruh pegawai pada Puskesmas Mangasa yang berjumlah 36 orang.

\section{Sampel}

Sampel ditentukan dengan teknik sampling jenuh (sensus) dimana semua populasi dijadikan sampel. Jadi sampel dalam penelitian ini adalah 36 orang yang terdiri dari 29 orang pegawai dan 7 orang pegawai honor Puskesmas Mangasa di Makassar.

\section{Metode Analisis}

Metode analisis data yang digunakan dalam penelitian ini, adalah analisis dengan alat statistik ini digunakan untuk mengetahui pengaruh variabel independen (X) terhadap variabel dependen (Y). Sugiyono (2013:103), untuk menguji hipotesis dalam penelitian ini digunakan model sebagai berikut:

$$
\mathbf{Y}=\boldsymbol{\beta}_{\mathbf{0}}+\boldsymbol{\beta}_{1} \mathbf{X}_{1}+\boldsymbol{\beta}_{2} \mathbf{X}_{2}+\mathbf{e}
$$

Dimana :

$$
\begin{array}{ll}
\mathrm{Y} & =\text { Kepuasan Kerja } \\
\mathrm{X}_{1} & =\text { Pengembangan Karir } \\
\mathrm{X}_{2} & =\text { Iklim Organisasi } \\
\beta_{0} & =\text { Bilangan Konstanta } \\
\beta_{1}-\beta_{2} & =\text { Koefisien Regresi Berganda } \\
\mathrm{e} & =\text { Error }
\end{array}
$$

Uji hipotesis dilakukan dengan cara:

a. Uji Regresi Simultan (Uji Statistik F) Uji statistik $F$ dilakukan dengan tujuan untuk menguji apakah keseluruhan variabel independen mempunyai pengaruh secara bersama-sama terhadap variabel dependen. Ghozali (2011:155). Pengujian simultan ini dilakukan dengan berpedoman pada hipotesis uji berikut:

$\mathrm{H}_{0} ; \beta_{\mathrm{i}}=0$ melawan $\mathrm{H}_{\mathrm{a}} ; \beta \neq 0$

Kriteria pengujian :

Jika $F_{\text {hitung }}<\mathrm{F}_{\text {tabel }}$ atau $\mathrm{P}>0,05$ maka $\mathrm{H}_{0}$ diterima

Jika $F_{\text {hitung }} \geq \mathrm{F}_{\text {tabel }}$ atau $\mathrm{P}<0,05$ maka $\mathrm{H}_{0}$ ditolak

Jika $\mathrm{H}_{0}$ diterima, berarti secara simultan, semua koefisien regresi tidak berbeda nyata nilainya dengan 0 pada tingkat kepercayaan $95 \%$. Dengan demikian, hasil analisis regresi tidak dapat dipakai untuk melakukan pendugaan secara statistic, seperti membuat ramalan, mengukur korelasi dan determinasi. Sebaliknya jika $\mathrm{H}_{0}$ ditolak, berarti secara simultan (bersama-sama) 
semua koefisien regresi berbeda nyata nilainya dengan 0 pada tingkat kepercayaan 95\%. Dengan demikian, hasil analisis regresi dapat dipakai untuk melakukan pendugaan secara statistik.

b. Uji Statistik $t$

Uji statistik $t$ pada dasarnya menunjukkan pengaruh variabel independen secara individual dalam menerangkan variasi variabel dependen. Untuk mengetahui ada tidaknya pengaruh masing-masing variabel bebas secara individual terhadap variabel terikat digunakan tingkat signifikan 5\% (Ghozali, 2011:156). Pengujian parsial ini dilakukan dengan maksud untuk menguji hipotesis, yaitu:

$\mathrm{H}_{0} ; \beta_{\mathrm{i}}=0$ melawan $\mathrm{H}_{\mathrm{a}} ; \beta \neq 0$

Kriteria pengujian :

Jika $t_{\text {hitung }}<\mathrm{t}_{\text {tabel }}$ atau $\mathrm{P}>0,05$ maka $\mathrm{H}_{0}$ diterima

Jika $t_{\text {hitung }} \geq \mathrm{t}_{\text {tabel }}$ atau $\mathrm{P}<0,05$ maka $\mathrm{H}_{0}$ ditolak

Jika $\mathrm{H}_{0}$ diterima, berarti secara parsial, semua koefisien regresi tidak berbeda nyata nilainya dengan 0 pada tingkat kepercayaan $95 \%$. Dengan demikian, hasil analisis regresi tidak dapat dipakai untuk melakukan pendugaan secara statistic, seperti membuat ramalan, mengukur korelasi dan determinasi. Sebaliknya jika $\mathrm{H}_{0}$ ditolak, berarti secara simultan semua koefisien regresi berbeda nyata nilainya dengan 0 pada tingkat kepercayaan 95\%. Dengan demikian, hasil analisis regresi dapat dipakai untuk melakukan pendugaan secara statistik

\section{HASIL PENELITIAN DAN PEMBAHASAN \\ 1. Pengaruh Pengembangan Karir terhadap Kepuasan Kerja}

Pengembangan karier adalah proses mengidentifikasi potensi karier pegawai dan materi serta menerapkan cara-cara yang tepat untuk mengembangkan potensi tersebut. Secara umum proses pengembangan karier di mulai dengan mengevaluasi kinerja karyawan dan proses ini lazim disebut sebagai penilaian kerja. Berdasarkan hasil uji regresi berganda, pengaruh variabel pengembangan karir berpengaruh positif dan signifikan terhadap kepuasan kerja pada pegawai Puskesmas Mangasa di Makassar.

Pengembangan karir di Puskesmas Mangasa di Makassar pada dasarnya adalah peningkatan kinerja pegawai yang mencerminkan kemampuan organisasi dalam bekerja, artinya kinerja masingmasing karyawan di nilai dan di ukur dalam nilai dan kriteria yang sudah ditentukan oleh organisasi. Pengembangan karir pegawai pada Puskesmas Mangasa di Makassar menupakan peningkatan tingkat pekerjaan seseorang dari satu level ke level lainnya baik secara horizontal berupa ke tempat yang lebih baik ataupun ke jabatan yang lebih tinggi. Bagi pegawai Puskesmas Mangasa di Makassar pengembangan karir merupakan sebuah strategi manajemen sumber daya manusia untuk menarik talenta-talenta berbakat agar tertarik dan mau bekerja dan mencurahkan kemampuan mereka untuk bekerja pada organisasi tersebut.

Pengembangan karir ini dimaksudkan agar para pegawai dapat terus bekerja di organisasi dalam jangka waktu yang lama ataupun bahkan seluruh usia kerjanya dicurahkan pada organisasi tersebut. Pegawai yang merasa bahwa pengembangan karir pada Puskesmas Mangasa di Makassar dibuat dan dirancang dengan baik dan berbasis pada kinerja kerja atau prestasi kerja akan merasa puas untuk terus bekerja di organisasi tersebut. Hal ini perlu agar tidak terjadi perpindahan pegawai yang 
berkualitas dan memiliki kemampuan tinggi dari perusahaan atau organisasi tersebut. Dengan adanya perencanaan dan pengembangan karir, keuntungan yang jelas bagi pegawai Puskesmas Mangasa di Makassar adalah kepuasan, pengembangan pribadi, dan kehidupan kerja yang berkualitas.

Hasil Penelitian ini sejalan dengan penelitian Oktriwani dan Kasmiruddin (2017) yang menunjukkan bahwa pengembangan karir berpengaruh signifikan terhadap kepuasan kerja karyawan Alpha Hotel Pekanbaru. Iklim organisasi berpengaruh signifikan terhadap kepuasan kerja karyawan Alpha Hotel Pekanbaru. Dan pengaruh pengembangan karir dan iklim organisasi berpengaruh signifikan terhadap kepuasan kerja karyawan Alpha Hotel Pekanbaru.

\section{Pengaruh Iklim Organisasi terhadap Kepuasan Kerja}

Iklim organisasi merupakan kualitas lingkungan internal organisasi yang secara relatif terus berlangsung, dialami oleh anggota organisasi, mempengaruhi perilaku mereka dan dapat dilukiskan ke dalam karakteristik atau sifat organisasi. Berdasarkan hasil uji regresi berganda, pengaruh variabel iklim organisasi berpengaruh positif dan signifikan terhadap kepuasan kerja pada pegawai Puskesmas Mangasa di Makassar.

Jika iklim organisasi pada pegawai Puskesmas Mangasa di Makassar kondusif dan suasana lingkungan manusia yang familiar maka akan membuat pegawai menjadi termotivasi karena puasnya pegawai terhadap iklim organisasi, namun sebaliknya jika iklim organisasi tidak kondusif maka mengakibatkan pegawai kurang bergairah dalam bekerja. Kepuasan kerja pegawai pada Puskesmas Mangasa di Makassar bisa terjadi jika pegawai merasa memperoleh perasaan keadilan dalam melakukan pekerjaan. Adanya iklim organisasi yang dirasa adil akan mendorong pegawai untuk segera mencapai kepuasan dalam bekerja. Iklim organisasi pada pegawai Puskesmas Mangasa di Makassar merupakan gambaran yang obyektif mengenai lingkungan kerja sedangkan kepuasan pegawai tanggapan perasaan mengenai lingkungannya. Iklim organisasi berpengaruh positif terhadap kepuasan kerja yaitu prestasi kerja sehingga hal ini dapat mempengaruhi kepuasan kerja secara langsung.

Hasil penelitian ini sejalan dengan penelitian Ayudiarini (2015) yang menunjukkan bahwa dalam uji regresi berganda diketahui yakni iklim organisasi dan pengembangan karir secara bersama-sama maka akan memiliki penganuh signifikan, sementara untuk iklim organisasi sendiri memiliki pengaruh signifikan terhadap kepuasan kerja karyawan, sedangkan untuk pengembangan karir terhadap kepuasan juga memiliki pengaruh signifikan terhadap kepuasan kerja. Demikian halnya dengan penelitian Yulianto (2016) yang menunjukkan bahwa secara bersama-sama iklim organisasi dan pengembangan karir berpengaruh terhadap kepuasan kerja karyawan yang sedang (cukup kuat atau cukup erat) bahwa iklim organisasi dan pengembangan karir dengan kepuasan kerja karyawan tidak terlalu dominan saling mempengaruhinya. Pengembangan karir memiliki pengaruh yang tinggi terhadap kepuasan kerja, faktor yang mempengaruhi terhdap kepuasan kerja yaitu prestasi kerja dan dukungan dari bawahan. Karyawan yang berprestasi seharusnya mendapatkan promosi dalam meningkatakan suatu jabatan atau promosi jabatan untuk meningkatkan kepuasan kerja.

\section{KESIMPULAN}

Dari hasil penelitian dan pembahasan yang telah dikemukakan sebelumnya, 
maka simpulan yang dapat ditarik oleh peneliti adalah sebagai berikut :

1. Pengembangan karir berpengaruh positif dan signifikan terhadap kepuasan kerja pada pegawai Puskesmas Mangasa di Makassar, sehingga hipotesis yang diajukan diterima.

2. Iklim organisasi berpengaruh positif dan signifikan terhadap kepuasan kerja pada pegawai Puskesmas Mangasa di Makassar, sehingga hipotesis yang diajukan diterima.

\section{SARAN}

Berdasarkan simpulan yang dikemukakan, maka saran-saran yang dapat di berikan oleh peneliti, adalah:

1. Diharapkan Puskesmas Mangasa di Makassar mengevaluasi dan menyesuaikan pelatihan dan pengembangan sesuai dengan masalah yang dihadapi sehingga dapat menyelesaikan pekerjaan secara mandiri walaupun pegawai yang ada adalah PNS yang sudah memiliki kriteria karir yang jelas.

2. Diharapkan Puskesmas Mangasa di Makassar memberikan studi dan menciptakan iklim organisasi yang lebih kondusif.

3. Diharapkan pimpinan perusahaan menambah peran untuk anggotanya dengan menggunakan jabatan sesuai struktur organisasi Puskesmas Mangasa di Makassar.

4. Diharapkan pimpinan perusahaan Puskesmas Mangasa di Makassar mengevaluasi dan meningkatkan rencana, visi dan misi perusahaan dengan menyesuaikan kemampuan SDM pada perusahaan.

\section{DAFTAR PUSTAKA}

Nawawi Hadari. 2013. Manajemen Strategik Organisasi Non Profit Bidang Pemerintahan. Gajah Mada University Press. Yogyakarta.
Marihot Tua Efendi. 2010. Manajemen Sumber Daya Manusia (Cetakan Keempat). Penerbit: Grasindo. Jakarta.

Rivai, Veithzal. 2013. Manajemen Sumber Daya Manusia Untuk Perusahaan Dari Teori ke Praktik. Edisi 2. Rajagrafindo. Jakarta.

Litwin, George H. dan Stringer, Robert A. 2008. Motivation and Organizational Climate. Harvard University

Husein Umar, 2014. Riset Sumber Daya Mamusia dalam Organisasi. Jakarta.

Handoko, Hani. 2011. Strategi Organisasi, Amara Books, Yogyakarta.

Mangkunegara. 2015. Evaluasi Kinerja Sumber Daya Manusia. Penerbit: Rafika Aditama. Bandung.

Rosidah dan Ambar, Teguh Sulistiyani. 2012. Manajemen Sumber Daya Manusia; Konsep teori dan Pengembangan SDM dalam konteks Organisasi Publik. Graha Ilmu Yogyakarta.

Suoder. William H. 2007. Self: American Masters. TV series documentary Himself

Timpe, Dale. 2012. Seri Ilmu dan Seni Manajemen Bisnis (Memimpin Manusia) PT. Alex Media Komputindo, Jakarta.

Robbins. 2011. Perilaku Organisasi (10th ed), New Jersey.

Siagian, Sondang P. 2012. Manajemen Sumber Daya Manusia, Cetakan keempat, Penerbit: Bumi Aksara. Jakarta. 
Taguari, R. dan Lidwin G. 2008 www.scielo.br/scielo.php $=$ S1516. Terjemahan FM Quintela.

Wirawan, 2011. Evaluasi Kinerja Sumber Daya Manusia, Teori, Aplikasi, Dan Penelitian, Penerbit: Salemba Empat. Jakarta.

Davis, Keith, dan John W., Newstroom. 2011. Perilaku dalam Organisasi (terjemahan). Erlangga. Jakarta.

Gilmer, B. Van Haller. 2011. Industrial Psychology 2nd Edition. New York: Mc Graw-Hill, Inc.

Davis, Keith. 2012. Human Behavior at Work Organizational Behavior, New Delhi, tata Mc. Graw Hill Publishing Company.

Milton, C.R. 2011. Human Behavior in Organization : Three Levels of Behavior. New York : PrenticeHall, Inc.
Sugiyono. 2013. Metode Penelitian Bisnis (Pendekatan Kuantitatif, Kualitatif, dan R\&D). Penerbit: Alfabeta. Bandung.

Oktriwani dan Kasmirudin. 2017. Pengaruh Pengembangan Karir dan Iklim Organisasi Terhadap Kepuasan Kerja Karyawan (Studi Kasus Alpha Hotel Pekanbaru). JOM FISIP. Vol 4 No 2. Universitas Riau.

Ayudiarini Natassia. 2015. Pengaruh Iklim Organisasi dan Pengembangan Karir Terhadap Kepuasan Kerja. Artikel Ilmiah Mahasiswa. Kapuk Valley Depok.

Yulianto, Eko Prasetyo. 2016. Iklim organisasi dan Pengembangan Karir Terhadap Kepuasan Kerja (Survei Pada Karyawan Universitas Komputer Indonesia). Jurnal Ilmiah Mahasiswa. Universitas Komputer Indonesia. 